\title{
Liquid Biopsy in Glioblastoma: Opportunities, Applications and Challenges
}

\author{
Ander Saenz-Antoñanzas ${ }^{1}$, Jaione Auzmendi-Iriarte ${ }^{1}$, Estefania Carrasco-Garcia 1,2, \\ Leire Moreno-Cugnon ${ }^{1}$, Irune Ruiz 1,2,3 ${ }^{(D}$, Jorge Villanua 1,3, Larraitz Egaña 1,3, \\ David Otaegui ${ }^{4,5}{ }^{D}$, Nicolás Samprón ${ }^{1,2,3, *}$ and Ander Matheu 1,2,6,* \\ 1 Cellular Oncology group, Biodonostia Health Research Institute, E-20014 San Sebastian, Spain \\ CIBER de Fragilidad y Envejecimiento Saludable (CIBERfes), 28029 Madrid, Spain \\ Donostia Universitary Hospital, 20014 San Sebastian, Spain \\ Multiple Sclerosis group, Biodonostia Health Research Institute, 20014 San Sebastian, Spain \\ Spanish Network of Multiple Sclerosis, 08028 Barcelona, Spain \\ 6 IKERBASQUE, Basque Foundation for Science, 48013 Bilbao, Spain \\ * Correspondence: nicolas.sampron@me.com (N.S.); ander.matheu@biodonostia.org (A.M.)
}

Received: 15 May 2019; Accepted: 4 July 2019; Published: 5 July 2019

\begin{abstract}
Liquid biopsy represents a minimally invasive procedure that can provide similar information from body fluids to what is usually obtained from a tissue biopsy sample. Its implementation in the clinical setting might significantly renew the field of medical oncology, facilitating the introduction of the concepts of precision medicine and patient-tailored therapies. These advances may be useful in the diagnosis of brain tumors that currently require surgery for tissue collection, or to perform genetic tumor profiling for disease classification and guidance of therapy. In this review, we will summarize the most recent advances and putative applications of liquid biopsy in glioblastoma, the most common and malignant adult brain tumor. Moreover, we will discuss the remaining challenges and hurdles in terms of technology and biology for its clinical application.
\end{abstract}

Keywords: liquid biopsy; glioblastoma; ctDNA

\section{Glioblastoma}

Glioblastoma is the most frequent, malignant and lethal primary brain tumor in adults. The World Health Organization (WHO) has classified it as a grade IV astrocytoma, the highest grade of malignancy, according to the histopathological, molecular and clinical features of these tumors [1]. Importantly, glioblastoma represents approximately $15 \%$ of all brain tumors and accounts for $50 \%$ of gliomas, with its incidence ranging from 1 to 5 cases per 100,000 individuals per year [2]. It presents an average survival of only 12-15 months from the time of diagnosis, standing as a highly aggressive tumor with an associated 5-year survival of less than 5\%. The current therapeutic approach is maximal surgical resection, followed by concomitant radiotherapy and chemotherapy with temozolomide $(\mathrm{TMZ})[3,4]$. However, glioblastoma's markedly proliferative, heterogeneous and chemoresistant nature highly compromises the available therapeutic options, leading to recurrence and death [1].

High-throughput large-scale sequencing analyses by The Cancer Genome Atlas (TCGA) have allowed a deep understanding of the molecular landscape of glioblastoma and have identified commonly deregulated genes and pathways such as growth factor signaling (RTK/Ras/PI3K), p53 and $\mathrm{Rb}$ signaling pathways [5,6]. These genetic and transcriptomic profiling analyses established a molecular classification comprising four subtypes: classical, mesenchymal, proneural and neural, although the latter was not clearly defined [7]. Thus, classical, mesenchymal and proneural subtypes are each mainly defined by aberrations in the gene expression of EGFR, NF1 and PDGFRA/IDH1, 
respectively [7]. The distinct subclasses differ in pathological features as well as in clinical characteristics and are associated with different therapy response. Indeed, classical and mesenchymal glioblastomas present improved survival rates that correlate with their better response to conventional therapy, whereas this therapy does not improve the survival in patients with the proneural subtype, although this group presents the best outcome [7]. Such an outcome is explained by the global pattern of hypermethylation, referred to as the glioma-CpG island methylator phenotype or G-CIMP, which is closely related to the presence of IDH1/2 mutations [8,9]. Nowadays, IDH1/2 mutational status, rather than the subtypes described above, is the routine diagnostic molecular marker to differentiate among glioblastoma tumors, defining an IDH wild-type or mutant genotype [1]. In addition to the intertumoral heterogeneity, great heterogeneity also exists within each tumor due to the presence of different cellular populations or clones with distinct genetic or expression profiles. Among these, the glioma stem cell (GSC) subpopulation displays stem cell characteristics such as unlimited self-renewal capacity and multilineage differentiation potential, being responsible for tumor initiation and progression. Furthermore, since conventional therapies directly target proliferative cells, the undifferentiated and quiescent GSC population can lead to therapy resistance and frequently to tumor recurrence [10], all together forming a complex ecosystem that current models, aiming to study the biology of the tumor, are unable to recapitulate.

Overall, glioblastoma's high heterogeneity at multiple levels (genomic, morphological, cellular, clinical and functional) hinders diagnosis and adequate therapeutic intervention, emphasizing the need to identify biomarkers for early diagnosis that allow a correct patient stratification and tailored therapy. Moreover, the dismal prognosis of glioblastoma highlights the need to unravel the critical molecular mechanisms underlying its progression to develop novel personalized therapeutic strategies.

\section{Use of Liquid Biopsy in Glioblastoma}

At present, DNA and RNA are generally used to define a tumor's molecular profile. However, the procedures for tumor tissue extraction are invasive, expensive and with risk to the patient. Moreover, tissue biopsies represent a small and localized region of the tumors and, therefore, might not fully capture the intratumoral heterogeneity. Furthermore, since the molecular landscape of the tumor evolves dynamically over time, biopsies might not be representative samples of the tumor, as patients cannot undergo such an invasive procedure repeatedly for the acquisition of samples. Recently, precision oncology and liquid biopsy have emerged as promising sources of biomarkers for diagnostic and prognostic purposes. In this regard, the analysis of biological body fluids has been shown to have the potential to determine the genomic profile of patients with cancer [11].

Glioblastomas are mainly diagnosed through neuroimaging techniques (e.g., magnetic resonance imaging (MRI) or computer tomography (CT) scans) and tissue samples, but they all have limitations [12]. For instance, MRI can only detect established tumors with sufficient mass. Moreover, the lack of accessibility to some brain tumors hampers obtaining tissue samples. The invasiveness of the procedure confers high risks to patients, such as brain swelling or hemorrhages that could result in deregulation of the brain function. Additionally, repeated surgery and sampling in order to define the real molecular profile of the tumor progression is not always possible. For these reasons, liquid biopsy appears as a promising approach to detect, molecularly characterize and monitor brain tumors and glioblastomas in particular [12]. A liquid biopsy might have some advantages versus tissue biopsy. It represents a simple and less invasive procedure that can provide similar information from certain body fluids (mainly blood) than what is usually obtained from a tissue biopsy sample [13]. It also has a potential clinical utility that could facilitate the early detection of cancer as well as improve patient follow up by managing tumor progression and monitoring therapy response $[13,14]$. In addition, this procedure could enable the identification of disrupted signaling pathways, the molecular subtype classification and also biomarker discovery. Importantly, liquid biopsies could be obtained regularly over time, reflecting the real composition, the tumoral heterogeneity and the evolution of the tumor throughout time. 
Several biological analytes such as circulating tumor cells (CTCs), circulating cell-free DNA (cfDNA) that contains circulating tumor DNA (ctDNA) in cancer patients, circulating cell-free tumor RNA (ctDNA) containing mRNAs and mainly small RNAs, extracellular vesicles (EVs), proteins, metabolites and tumor-educated platelets (TEPs) are found in body fluids and could be sampled within a liquid biopsy (Figure 1). This circulating material can derive from tumor tissue and thus, can provide a real and representative sample of the glioblastoma. Indeed, the genomic profiles of ctDNA in liquid biopsies and the corresponding tumor have been found to closely match and correlate. Moreover, rapid turnover of glioblastoma cells could result in a constant release of tumor-derived nucleic acids and vesicles into circulation. Additionally, viable tumor cells could enter the bloodstream once separated from the neoplasm. In the following sections, we will describe the information obtained in liquid biopsies components derived from blood and cerebrospinal fluid (CSF) of glioblastoma patients.

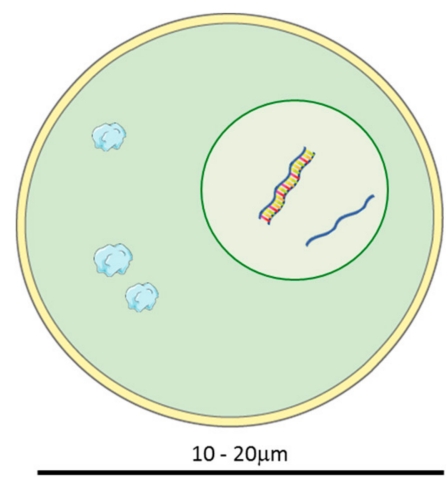

Circulating tumor cells

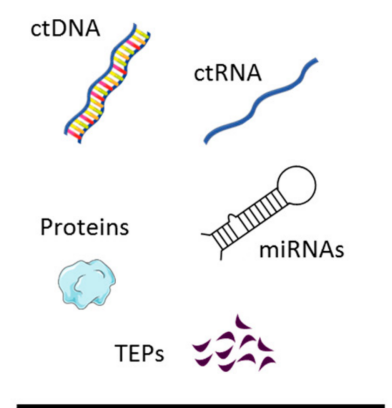

Cell free fraction

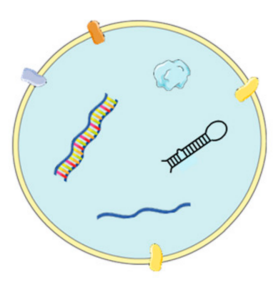

40 - >1000nm

Extracellular vesicles

Figure 1. Components found in liquid biopsy (blood or cerebrospinal fluid) of glioblastoma patients. Liquid biopsies of tumor-specific circulating components include circulating tumor cells (CTCs), circulating cell-free tumor DNA (ctDNA) and RNA (ctRNA), circulating microRNAs (miRNAs), proteins, tumor-educated platelets (TEPs) and extracellular vesicles (EVs).

\section{Liquid Biopsy Components from Blood}

\subsection{Cell-Free Nucleic Acids}

Among the different types of materials that can be found in the blood of cancer patients, cell-free nucleic acids, ctDNA and ctRNA, are the most prevalent and well-studied components (Table 1). In particular, an increased amount of ctDNA has been found in blood samples from cancer patients, including glioblastoma, compared to control individuals or individuals with benign or low-grade tumors; indeed, the ctDNA level has been shown to positively correlate with tumor stage [12,15]. In glioblastoma, the presence of brain tumor-derived ctDNA in plasma is low compared to other cancers, mainly because of the presence of the blood-brain barrier (BBB), in contrast to other tumors that are able to transfer ctDNA fragments into blood [16,17]. For ctDNA analyses, plasma samples are preferable to serum ones because they represent a good source of ctDNA and lack background levels of cfDNA, which are higher in serum probably due to contamination with DNA released from immune cells lysed during the clotting process [18]. Nonetheless, plasma often contains low levels of ctDNA that vary between patients [16]. The exact mechanisms by which ctDNA is released into blood are still unclear; however, apoptosis and necroptosis are suggested as possible sources, since apoptosis is the principal source for both total cfDNA and ctDNA based on the size distribution analysis of cfDNA $[19,20]$. Additionally, macrophages seem to play a role in the liberation of tumor-derived DNA fragments into circulation via the phagocytosis of necrotic neoplastic cells. 
Table 1. Components identified in the blood of glioblastoma patients.

\begin{tabular}{|c|c|c|c|c|c|}
\hline Liquid Biopsy Component & Molecule & Example & $\begin{array}{c}\text { Information Provided and } \\
\text { Findings }\end{array}$ & Clinical Applicability & Reference \\
\hline \multirow{21}{*}{ Cell-free components } & \multirow{5}{*}{ ctDNA } & MGMT & promoter methylation status & therapy response & [21] \\
\hline & & MGMT & promoter methylation status & diagnosis & [22] \\
\hline & & IDH1, EGFR, TP53, PTEN & mutations & molecular profiling/diagnosis/prognosis & [16] \\
\hline & & TP53, NF1, MET, APC, PDGFRA & mutations & molecular profiling/treatment selection & [23] \\
\hline & & $M E T, E G F R, E R B B 2$ & amplifications & molecular profiling/treatment selection & [23] \\
\hline & \multirow{10}{*}{ miRNA } & miR-15b & downregulated & diagnosis & {$[24,25]$} \\
\hline & & miR-23a, miR-133a, miR-150, miR-197, miR-548b & downregulated & diagnosis & [24] \\
\hline & & miR-128, miR-342 & downregulated & therapy response/diagnosis & [25] \\
\hline & & miR-125b & downregulated & diagnosis & {$[26,27]$} \\
\hline & & $\mathrm{miR}-497$ & downregulated & diagnosis & {$[24,26]$} \\
\hline & & miR-205 & downregulated & diagnosis/prognosis/tumor evolution monitoring & [28] \\
\hline & & miR-21 & upregulated & diagnosis/prognosis/therapy response & {$[25,29]$} \\
\hline & & miR-221, miR-222 & upregulated & prognosis & [30] \\
\hline & & miR-454 & upregulated & prognosis & [31] \\
\hline & & miR-210, miR-182 & upregulated & diagnosis & {$[32,33]$} \\
\hline & \multirow{3}{*}{$\operatorname{lncRNA}$} & HOTAIR & upregulated & diagnosis/prognosis & [34-36] \\
\hline & & GAS5 & downregulated & prognosis/therapy response & [35] \\
\hline & & MALAT1, H19 & deregulated & prognosis & [35] \\
\hline & \multirow{3}{*}{ Protein } & Haptoglobin $\alpha 2$ & high levels & diagnosis/prognosis & [37] \\
\hline & & YKL-40 & high levels & prognosis & {$[38,39]$} \\
\hline & & AHSG & high levels & prognosis & {$[40]$} \\
\hline \multirow{7}{*}{ EVs } & \multirow{5}{*}{ DNA } & EGFR & amplification & diagnosis & [41] \\
\hline & & PTEN & deletion & diagnosis & [41] \\
\hline & & TP53, IDH1/2 & mutations & diagnosis & [41] \\
\hline & & EGFRvIII, IDH1, PTEN & mutations & diagnosis/prognosis & {$[42,43]$} \\
\hline & & MGMT & high expression & therapy response & {$[44]$} \\
\hline & \multirow{2}{*}{ Protein } & PD-L1 & surface expression & prognosis/therapy response & [45] \\
\hline & & TGM2, CD44, CD133 & high levels & therapy response & [46] \\
\hline \multirow{3}{*}{ CTCs } & \multirow{3}{*}{ DNA } & SERPINE1, TGFB1, TGFBR2, VIM & high expression & diagnosis/prognosis & [47] \\
\hline & & EGFR & amplification & prognosis & {$[48,49]$} \\
\hline & & SOX2, OCT4, NANOG & expression & prognosis & {$[50,51]$} \\
\hline TEPs & & EGFRvIII & mutation & diagnosis & [52] \\
\hline
\end{tabular}

Circulating tumor DNA (ctDNA), microRNA (miRNA), long non-coding RNA (lncRNA), extracellular vesicles (EVs), circulating tumor cells (CTCs), tumor-educated platelets (TEPs), O6-methylguanine-DNA-methyltransferase (MGMT), isocitrate dehydrogenase (IDH), epidermal growth factor receptor (EGFR), tumor protein p53 (TP53), phosphatase and tensin homolog $(P T E N)$, neurofibromin 1 (NF1), MET proto-oncogene receptor tyrosine kinase (MET), APC regulator of Wnt signaling pathway (APC), platelet derived growth factor receptor alpha (PDGFRA), ErbB2 receptor tyrosine kinase 2 (ERBB2), HOX antisense intergenic RNA (HOTAIR), growth arrest-specific transcript 5 (GAS5), metastasis associated in lung adenocarcinoma transcript 1 (MALAT1), H19 imprinted maternally-expressed transcript (H19), epidermal growth factor receptor variant III (EGFRvIII), programmed death ligand 1 (PD-L1), transglutaminase 2 (TGM2), serpin family E member 1 (SERPINE1), transforming growth factor beta 1 (TGFB1), transforming growth factor beta receptor 2 (TGFBR2), vimentin (VIM), SRY (sex determining region Y)-box 2 (SOX2), octamer-binding transcription factor 4 (OCT4), and nanog homeobox (NANOG). 
Since ctDNA quantification from plasma samples is challenging due to the low amount of biological material available [16], improvement in sequencing technologies is necessary. In this sense, the development of new technologies such as droplet-based digital PCR (ddPCR) [53] or the optimization of next generation sequencing (NGS) techniques [54] have improved the sensitivity and specificity for the detection of ctDNA mutations [55]. While NGS allows exploring a wide range of nucleic acids present in a sample with high sensitivity and reproducibility, with the use of ddPCR, the target sequences can be individually tested allowing rare event detection and quantification at the level of a single molecule. On the other hand, NGS can detect novel and unknown genetic modifications but longer time is needed to obtain, process or analyze the results; moreover, it requires bioinformatics expertise and it is more expensive [16]. In comparison with NGS, ddPCR experiments are easier to set up, faster, present higher sensitivity, lower costs and they do not need complex bioinformatic analysis. However, they only enable the study of known mutations [56]. In this sense, a technique comparison study comprising 62 glioblastoma samples to detect IDH1 mutations by Sanger direct sequencing, ddPCR or quantitative real-time PCR (qRT-PCR) showed that ddPCR was more sensitive method to screen for IDH1 mutations [57].

Few studies have analyzed and identified tumor-associated mutations in blood samples. An initial study detected IDH1, EGFR, TP53 and PTEN mutations in a limited subset (10\%) of patients with glioblastoma [16]. More recent studies performing comprehensive ctDNA analysis and a highly sensitive and specific NGS assay yielded approximately $50 \%$ of the ctDNA detection rate in patients with advanced glioblastoma and showed that the ctDNA detection rate in gliomas may vary by grade and histopathology [23,58]. A similar NGS analysis of plasma-derived ctDNA extracted from a total of 171 patients with different cancers, including 33 patients with glioblastoma, successfully determined the most frequent mutations in the TP53, EGFR, MET, PIK3CA and NOTCH1 genes [59]. In other studies, the most frequent somatic mutations detected using NGS technology were observed in TP53, NF1, EGFR1, MET, APC and PDGFRA genes together with amplifications of ERBB2, MET and $E G F R$, among others [23]. These results should be confirmed by more sensitive techniques such as ddPCR or improved NGS; nevertheless, the spectrum of mutated genes is similar to that obtained by TCGA tissue analysis [5,6]. Thus, ctDNA might provide a comprehensive view of the glioblastoma genome, as it might reflect DNA derived from multiple tumor regions and could serve as a diagnostic biomarker. Since some of those mutations have been used to molecularly classify glioblastoma (EGFR amplification associated with classical, NF1 and TP53 mutations with mesenchymal or IDH1 mutation with proneural subtypes), these results also suggest that plasma ctDNA analysis might be an option to obtain actionable somatic genomic information and reveal the molecular profile or subtypes of glioblastoma patients. This might also guide clinical therapeutic selection. Indeed, BRAF/IDH1/IDH2 mutations, PDGFRA amplifications and mutations in DNA damage repair genes were proposed as potential candidates for molecular targeted therapy [23].

Moreover, epigenetic changes have also been detected in glioblastoma blood samples. Thus, methylation in promoter MGMT gene was observed in matched tissue and serum ctDNA from glioblastoma patients as well as correlated with clinical response to therapy [21]. Specifically, an improved response and time to progression after treatment with alkylating agents was reported in patients with increased serum levels of MGMT promoter methylation. Additionally, ctDNA from glioblastoma patients presented lower levels of Alu methylation than the controls [60], further supporting that ctDNA might provide a comprehensive view of the glioblastoma epigenome. A recent, sensitive immunoprecipitation-based protocol has been developed in order to study the methylome of small quantities of ctDNA to detect enrichment of tumor-specific patterns early in the progression of the disease [22]. It would be interesting to test this technique in future studies with glioblastoma samples.

Circulating cell-free tumor RNA (ctRNA) include mRNAs, long non-coding RNAs (lncRNAs) and mainly small ncRNAs. Small ncRNAs include in turn microRNAs (miRNAs), small interfering RNAs (siRNAs), circular RNAs (circRNAs), small nuclear RNAs (snRNAs) and small nucleolar RNAs (snoRNAs), which can be released into the extracellular medium to regulate several signaling 
pathways through repressing multiple genes at translational level. Among them, miRNAs have arisen as promising biomarkers for cancer diagnosis in the last decade [61]. These are small (18-23 nucleotides) endogenous ncRNAs involved in most physiological and pathological cellular events such as proliferation, differentiation, migration, invasion, senescence and survival by regulating post-transcriptional gene expression. miRNAs are the most abundant circulating free molecules in blood [62]. Moreover, detectable miRNA levels can be observed in additional cell-free body fluids as well as in tissues [63]. Thus, altered miRNA expression patterns in biological fluid samples correlate with tumor tissue samples and could improve early diagnosis, classification and prognosis prediction of different cancer types, including glioblastoma [63,64].

The expression of several miRNAs and lncRNAs has been reported as altered in glioblastoma patient samples $[65,66]$. In particular, a global serum miRNA signature in a large cohort of malignant glioma patients revealed that seven serum miRNA (miR-15b, miR-23a, miR-133a, miR-150, miR-197, miR-497 and miR-548b) levels were reduced in the serum of cancer patients compared to normal controls [24]. Significant upregulation of miR-21 and downregulation of miR-128 and miR-342 were also found in plasma and tissue samples from glioblastoma patients compared to healthy controls [24], postulating them as predictive biomarkers for diagnosis. Moreover, high-grade glioma patients presented lower miR-128 and miR-342 levels in plasma suggesting that these miRNAs positively correlate with histopathological grades of glioma [25]. Remarkably, their levels were restored after surgery and chemo-irradiation therapy, suggesting they could also be useful biomarkers for therapy response [25]. Interestingly, these miRNAs seem to be specific for gliomas, allowing the distinction between glioblastoma and other brain tumors, such as meningiomas or pituitary adenomas. Similarly, a restricted signature of serum miRNAs including miR-125b and miR-497 levels could distinguish high-grade and low-grade gliomas with a downregulation of these two miRNAs in glioblastoma patients compared to the lower grade group [26,27]. miR-205 represents another potential diagnostic biomarker, since it was found significantly decreased in serum from patients with glioblastoma, and its expression negatively correlated with the pathological grade of the tumor [28]. Of note, serum miR-205 levels increased after surgical resection of the tumor and dropped again upon recurrence, being a good candidate for tumor evolution monitoring. miRNAs can also be overexpressed in glioma samples. Specifically, miR-21expression was found highly expressed in glioblastoma patients and was described to inversely correlate with survival of those patients $[25,29]$. Furthermore, miR-21 could be a biomarker of therapeutic response since its levels diminished after chemo-radiation. Likewise, elevation of serum miR-221, miR-222, miR-210, miR-182 or miR-454 levels were observed in glioblastoma patients and also associated with tumor progression and low survival rates, which postulate them as good prognostic biomarkers [30-33]. These studies highlight the use of a panel comprising multiple miRNAs found in serum from glioblastoma patients as a potential strategy for diagnostic and prognostic purposes. However, the usefulness of miRNAs as biomarkers for disease can be controversial as different studies show distinct expression of the same miRNA in glioma cells, underscoring the careful selection that must be carried out in order to implement miRNAs as biomarkers for glioblastoma diagnosis in clinical practice [66]. Indeed, it has been proposed that miRNAs need to be validated in further research studies and clinical trials, as well as a standardization of sample processing, miRNA detection and statistical analysis methods should be established before implementing miRNAs as biomarkers in clinics [67].

LncRNAs are commonly involved in gene regulation, leading to several signaling pathway deregulation and ultimately promoting carcinogenesis [68]. Thus, they have emerged as potential diagnostic and prognostic biomarkers in glioblastoma [65]. Of note, lncRNA and miRNA functions are intimately correlated and indeed form a complex regulatory network that modulates each other's expression. They are key molecules in mRNA stabilization and degradation, but they are also involved in the miRNA sponge mechanism influencing multiple biological processes (expression at a post-transcriptional level, epigenetic regulation, cell growth and death) [65]. Several lncRNAs have been detected in blood samples from glioblastoma patients with differentially expressed levels 
compared to healthy individuals. Among them, the epigenetic regulators HOTAIR, GAS5, H19 and MALAT1 were found in serum and tumor samples from glioblastoma patients [34-36]. Interestingly, GAS5 has been related to the responsiveness of glioblastoma patients to TMZ, having potential therapy response prediction value. Additional ctRNAs, including siRNAs, circRNAs, snRNAs and snoRNAs have been detected as differentially expressed in glioblastoma blood and tumor samples. This reveals their potential as biomarkers for diagnosis and prognosis as well as suggests a role in the pathogenesis of the disease [69,70]; however, additional experiments and validations are required to support their roles.

\subsection{Extracellular Vesicles}

In recent years, EVs have boosted new opportunities for non-invasive diagnosis and monitoring of human cancer. EVs are small membrane-enclosed spheres (40 to $>1000 \mathrm{~nm}$ in diameter) produced and secreted by many different cell types through complex and tightly regulated molecular mechanisms [71,72]. The different types of EVs are classified depending on their biogenesis into exosomes $(40-200 \mathrm{~nm})$, membrane-derived vesicles $(40$ to $>1000 \mathrm{~nm})$ and apoptotic bodies (100-5000 nm) [73]. EVs are present in several body fluids such as blood, CSF or urine, and they have a diverse molecular composition including nucleic acids, proteins, lipids and metabolites that can be transferred to nearby or distant cells by direct EV-cell membrane contact, fusion or internalization [72,73]. Unlike ctDNA, EVs arise from viable cancer cells; consequently, these two analytes might reflect different aspects of tumor biology. The relevance of EVs is highlighted by the fact that their transcriptomic and proteomic profile is specific depending on the cell of origin and can vary in response to diverse stimuli. Indeed, EVs can carry tumor-specific material that might serve as a diagnostic and prognostic tool [74]. In addition, they participate in the modulation of cancer hallmarks by transmitting oncogenic signals to recipient cells in order to promote tumorigenic activities such as proliferation, survival and differentiation $[41,75,76]$. In addition to their stability, EVs hold the capacity to protect and maintain the integrity of their content, preventing degradation and enabling its further study. For instance, EV-derived DNA may be representative of the mutational status of parental tumor cells and could, therefore, be of relevance for genomic analysis [77].

The analysis of EVs detected in blood, CSF or any other biological fluid from glioblastoma patients is gaining interest and they are emerging as candidates to be useful diagnostic and prognostic biomarkers [75]. Thus, it has been described that plasma EV concentration is higher in glioblastoma patients compared to healthy controls and that the proteomic profiling of these EVs revealed a glioblastoma-distinctive signature with EGFR amplifications, PTEN deletions, and IDH1/2 and TP53 mutations [41]. Noteworthy, EVs can transgress anatomical compartments such as the BBB and that raise them as a potential source of biomarkers for glioblastoma to detect evolving changes relative to tumor progression $[42,43,78,79]$. Indeed, molecular alterations in various genes such as EGFRvIII, IDH1 and PTEN have been found in glioblastoma-derived EVs [43,78]. Moreover, EVs can mediate the crosstalk between glioblastoma and its microenvironment, exchanging signals between the brain cells and the surrounding stroma and altering the tumor milieu to provide a suitable environment for tumor growth [80]. In this sense, the interplay between EVs and anticancer immunity represents a novel area of research and potential biomarkers are starting to be identified [81]. PD-L1 expression has been found on the surface of glioblastoma-derived EVs [45]. These PD-L1 expressing EVs can prevent T cell activation and proliferation upon direct binding with PD-1, indicating that PD-L1 expression on EVs is an immune-escape mechanism for glioblastoma [45]. Interestingly, several studies have reported that TMZ treatment can affect EV release and confer drug resistance to recipient cells by horizontal transference of molecular cargos through EVs. For instance, EVs collected from TMZ-resistant patients showed increase expression levels of MGMT [44,46]. Moreover, TMZ-resistant cell-derived EVs present deregulated levels of cell adhesion-related proteins like transglutaminase 2 (TGM2), stemness markers such as NESTIN and glycoproteins such as CD44 and CD133 that are expressed in the surface of 
EVs $[46,82]$. This suggests that they could be exploited as cancer biomarkers to monitor TMZ failure through the analysis of their molecular components.

\subsection{Circulating Tumor Cells}

CTCs are tumor-derived cells that have entered the bloodstream or have been passively released from the primary tumor into circulation [83]. Their abundance in blood is very limited with only 1 CTC per $10^{9}$ blood cells, and their isolation is difficult due to the complexity of the required techniques. Negative-enrichment approaches are based on CTC size (CTCs are larger than normal blood cells) or other biophysical properties. Positive selection of CTCs can be achieved by the detection of specific tumor markers that are commonly expressed on the surface of these cells [84]. Nevertheless, these surface markers are not specific, hampering the distinction of CTCs from non-malignant cells. So, DNA, RNA or protein analyses have to be performed to fully analyze the content and identify CTCs. There are still few studies that relate CTCs to clinical applications, but the improvement of new techniques, such as single-cell analysis, have allowed the shift from the enumeration of CTCs to a more detailed genomic, transcriptomic, proteomic and epigenomic analyses of their content. This is providing us with valuable information that promotes the use of CTCs for diagnostic, prognostic or therapeutic purposes $[85,86]$. Even though it is difficult to detect them, the abundance of CTCs in the blood of patients with cancer has been proposed to have clinical utility as a biomarker for prognosis and might also be useful for therapeutic assessment [84,87]. CTCs have been detected in the blood of patients with different grades of glioma including glioblastoma, and they have been shown to be representative of the tumor $[48,49]$. In line with this, glioblastoma-derived CTCs presented EGFR amplification that was linked to aggressiveness and was associated with the presence of EGFRvIII [49]. Moreover, the single-cell expression analysis of 15 CTCs from seven independent glioblastoma patients revealed an elevated expression of SERPINE1, TGFB1, TGFBR2 and VIM genes associated with the mesenchymal subtype [47]. Additional studies have revealed that glioblastoma-derived CTCs possess stem cell properties contributing to local tumorigenesis and recurrence [50,51]. Indeed, cultured CTCs were described to express GSC markers including SOX2, OCT4, and NANOG and also present resistance to the treatment with radiotherapy or TMZ in comparison with cultured tissue-derived glioblastoma cells [50]. Despite being possible candidates for clinical applications in glioblastoma, the challenging isolation and the low number of CTCs detected restricts the number of available studies.

\subsection{Proteins and Metabolites}

Measurements of serum circulating proteins are currently being used in clinical practice to identify potential reliable biomarkers for cancer detection. Several studies have investigated specific serum-derived proteins for glioblastoma characterization. Thus, it has been reported that serum from patients with glioblastoma exhibited 27 differentially expressed proteins, of which five had been previously associated with the progression of the tumor [88]. Moreover, the expression of haptoglobin $\alpha 2$ was significantly elevated in glioma patients and positively correlated with tumor grade, being the highest levels detected in patients with glioblastoma [37]; this postulates haptoglobin as a candidate biomarker for glioblastoma diagnosis and prognosis. In contrast, chemo-irradiation did not alter the serum levels of haptoglobin $\alpha 2$ as they were only reduced after adjuvant therapy [89]. Glioblastoma biopsy samples and serum levels also displayed an elevated YKL-40 expression that was associated with worse prognosis and overall survival of patients [38,39]. Likewise, the serum AHSG concentration was found to be increased in glioblastoma patients and was associated with higher tumor grade and lower overall survival [40]. However, other studies have demonstrated no association between the serum levels of haptoglobin $\alpha 2$, YKL-40 or AHSG and progression-free survival [89].

Metabolism is critical in order to sustain cancer cell proliferation and adaptation to tough microenvironments. Thus, elucidating and understanding metabolic reprogramming is a key for biomarker discovery and development of therapeutic strategies. In this regard, circulating metabolite levels are interesting biomarker candidates for cancer detection and progression. So far, there are not 
many studies in glioblastoma but some of them support the use of some metabolites as biomarkers in liquid biopsies. Thus, metabolomic profiling identified arginine, methionine and kynurenate levels in plasma significantly associated with 2-year overall survival [90], revealing a metabolite profile predictive of glioblastoma prognosis. Moreover, an additional study revealed higher serum concentrations of $\alpha$-tocopherol and $\gamma$-tocopherol in serum samples from glioblastoma, postulating them as latent biomarkers for glioblastoma progression [91].

\subsection{Tumor-Educated Platelets}

TEPs are referred to as the platelets that have received tumor-associated molecules from neoplastic cells [92]. This biomolecule transfer process is known as "education". TEPs have been shown to actively contribute to cancer growth and metastasis, providing angiogenic factors to support vascularization. Indeed, angiogenesis-related proteins can be detected in platelets before the tumors have reached detectable sizes, suggesting a potential avenue for the early and minimally invasive detection of cancer $[93,94]$. Thus, it has been proposed that RNA from TEPs may complement the currently used biosources and biomolecules employed for liquid biopsy diagnosis, which would potentially enhance the detection of cancer in an early stage and facilitate noninvasive disease monitoring [94]. TEP RNAseq analyses of 228 localized and advanced metastatic cancer patients, comprising various tumor types including glioblastoma, evidenced different RNA profiles between cancer patients and healthy individuals. Indeed, discrimination between cancer patients from healthy individuals could be achieved with $84-96 \%$ accuracy by analyzing TEPs, being glioblastoma cases within the most accurate ones. Moreover, TEP profiling might serve to establish the organ of origin of the primary tumor with $71 \%$ accuracy and indeed TEP profiles were shown to be distinct between different molecular tumor subtypes based on EGFR and K-RAS [95]. Furthermore, it has been described that TEPs can take up EV-derived RNA. In this regard, TEPs from glioblastoma patients were shown to capture tumor-derived EVs containing mutant EGFRvIII. Remarkably, EGFRvIII mutation was detected in $80 \%$ of glioblastomas but not in healthy controls [52]. This finding probably extends to other tumor-related mutations, as RNA profiling from glioblastoma and healthy patients led to the identification of a glioblastoma-associated signature. Nonetheless, the utility of TEPs as non-invasive biomarkers for cancer diagnosis and classification remains to be fully demonstrated, since the "education" process is still poorly understood and the platelet subpopulations could change during the clinical course of glioblastoma patients [95].

\section{Liquid Biopsy in Cerebrospinal Fluid}

CSF is a colorless biological fluid produced by the specialized ependymal cells within the choroid plexuses of the brain ventricles. CSF is obtained through lumbar puncture, which is an invasive procedure that might be performed in patients harboring brain tumors, including glioblastoma. Since CSF is in direct contact with the central nervous system (CNS), liquid biopsy of CSF can be used to profile circulating biomarkers like cell-free nucleic acids (ctDNA and miRNAs), proteins, EVs or CTCs of glioblastoma patients (Table 2). Moreover, it could also be useful to detect circulating material from tumors that have metastasized to the brain. 
Table 2. Components identified in the cerebrospinal fluid (CSF) of glioblastoma patients.

\begin{tabular}{|c|c|c|c|c|c|}
\hline $\begin{array}{l}\text { Liquid Biopsy } \\
\text { Component }\end{array}$ & Molecule & Example & $\begin{array}{l}\text { Information Provided and } \\
\text { Findings }\end{array}$ & Clinical Applicability & Reference \\
\hline \multirow{14}{*}{ Cell-free components } & \multirow{5}{*}{ ctDNA } & IDH1, TP53, PTEN, EGFR, FGFR2, ERBB2 & mutations & diagnosis/prognosis & [17] \\
\hline & & IDH1, IDH2, TP53 & mutations & diagnosis/prognosis & [96] \\
\hline & & CDKN2A, CDKN2B & deletions & diagnosis/prognosis & [96] \\
\hline & & EGFR & amplification & diagnosis/prognosis & [96] \\
\hline & & MGMT, p16INK4a, TIMP3, THBS1 & promoter hypermethylation & Diagnosis & [97] \\
\hline & \multirow{3}{*}{ miRNA } & \multirow{3}{*}{$\begin{array}{c}\text { miR125b, miR-223, miR-451, miR-711, miR-935 } \\
\text { miR-21, miR-218, miR-193b, miR-331, miR374a, miR548c, miR520f, miR27b and } \\
\text { miR-30b } \\
\text { miR-21, miR-10b } \\
\text { miR-15b }\end{array}$} & upregulated & diagnosis/therapy response & [98] \\
\hline & & & upregulated & diagnosis/therapy response & {$[99,100]$} \\
\hline & & & $\begin{array}{l}\text { upregulated } \\
\text { upregulated }\end{array}$ & $\begin{array}{l}\text { diagnosis/prognosis/therapy response } \\
\text { prognosis/therapy response }\end{array}$ & {$[100-103]$} \\
\hline & \multirow{6}{*}{ Protein } & Tenascin & high levels & Diagnosis & [104] \\
\hline & & OPN & high levels & Diagnosis & [105] \\
\hline & & VEGF & high levels & diagnosis/prognosis & {$[106,107]$} \\
\hline & & $\mathrm{TNF} \alpha, \mathrm{CCL} 3, \mathrm{CCL} 4$ & high levels & diagnosis/prognosis & [106] \\
\hline & & FGF2 & high levels & diagnosis/prognosis & [107] \\
\hline & & NGF & high levels & prognosis/tumor progression & [108] \\
\hline \multirow{2}{*}{ EVs } & DNA & IDH1 & mutation & Diagnosis & [109] \\
\hline & miRNA & miR-21 & upregulated & diagnosis/prognosis & [82] \\
\hline
\end{tabular}

Circulating tumor DNA (ctDNA), microRNA (miRNA), extracellular vesicles (EVs), isocitrate dehydrogenase (IDH), tumor protein p53 (TP53), phosphatase and tensin homolog

$(P T E N)$, epidermal growth factor receptor (EGFR), fibroblast growth factor receptor 2 (FGFR2), ErbB2 receptor tyrosine kinase 2 (ERBB2), cyclin dependent kinase inhibitor (CDKN),

O6-methylguanine-DNA-methyltransferase (MGMT), TIMP metallopeptidase inhibitor 3 (TIMP3), thrombospondin 1 (THBS1), osteopontin (OPN), vascular endothelial growth factor

(VEGF), tumor necrosis factor alpha (TNF $\alpha$ ), C-C motif chemokine ligand (CCL), fibroblast growth factor 2 (FGF2), neural growth factor (NGF) 
The identification of glioblastoma biomarkers in CSF was first achieved by the detection of high levels of tenascin, an extracellular matrix glycoprotein, in brain tumor patients compared to other non-CNS primary tumors and control patients [104]. Similarly, elevated levels of osteopontin (OPN) were noted in CSF samples from glioblastoma patients compared to healthy control CSF [105]. An additional study found that cleaved OPN fragments in CSF were more abundant in glioblastoma patients and, after the analysis of consecutive CSF samples, they identified that these fragment levels were positively correlated with CSF levels of vascular endothelial growth factor (VEGF) (marker of angiogenesis) and TNF $\alpha$, CCL3 and CCL4 (indicators of inflammation) [106]. In this sense, the levels of VEGF and fibroblast growth factor 2 (FGF2) were shown to be significantly higher in patients with glioblastoma and associated with shorter overall survival rate, demonstrating the usefulness of these proteins as potential diagnostic and prognostic biomarkers [107]. Furthermore, the expression of the nerve growth factor (NGF) in CSF was found to be more elevated as the malignancy of the glioma increased [108]. More recently, a robust association between tumor type and tumor location with the presence of ctDNA in CSF has been described and correlated with disease burden, adverse outcome and shorter overall survival [17]. In this study, matched samples of CSF, plasma and tumor-derived tissue DNA from glioblastoma, medulloblastoma or brain metastasis were studied and highlighted the potential of CSF-derived ctDNA to characterize and monitor brain tumors in comparison to blood samples. Noteworthy, CNS malignancy-derived ctDNAs were more abundant in CSF than in plasma samples [17]. Similarly, a genome-wide sequencing study involving 35 patients with primary CNS tumors, could detect CSF ctDNA in $74 \%$ of the cases and in $100 \%$ of high-grade gliomas localized neighboring a CSF reservoir, whereas no ctDNA was noticed in patients with CNS tumors physically distant from this reservoir [110]. Thus, circulating components in CSF samples stand as an alternative source to blood to identify diagnostic and prognostic biomarkers in malignancies affecting the CNS.

The study of De Mattos-Arruda and collaborators also found mutations in IDH1/2, EGFR, PTEN, FGFR2 and ERBB2 genes in CSF samples, and showed that CSF ctDNA is longitudinally modulated throughout treatments after the observation of dynamic changes in CSF ctDNA, which recapitulates the treatment courses of patients with glioblastoma [17]. Thus, ctDNA from CSF could be used to study somatic mutations and monitor tumor burden. In this regard, a recent study in CSF from 85 glioblastoma patients revealed that ctDNA was detected in $49.4 \%$ of patients and associated with disease burden and adverse outcome [96]. Moreover, the genomic landscape included a broad spectrum of genetic alterations that closely resembled the genomes of tissue biopsies including mutations in TP53 and IDH1/2, deletions of CDKN2A and CDKN2B, and amplification of EGFR [96]. ctDNA mutations in IDH1/2 were shared in all matched ctDNA-positive CSF-tumor pairs and further analysis of CSF ctDNA revealed a broad spectrum of promoter mutations, copy number alterations and structural rearrangements [96]. Sequencing analysis also detected somatic alterations in a panel of 341 cancer-associated genes in the CSF ctDNA from patients with primary brain tumor or metastases from solid tumors, but not from patients without CNS affection by cancer [111]. These results suggest that CSF better captures genomic alterations and that is more representative of glioblastoma genetic alterations than plasma ctDNA, recapitulating the mutations from tissue samples. Noteworthy, promoter hypermethylation in MGMT, p16INK4a, TIMP-3 and THBS1 was detected at high frequencies in CSF, serum and tumor tissue, in all glioblastoma patients but not in any of the healthy individuals [97]. Hypermethylation in CSF and serum DNA was accompanied with methylation in the corresponding tumor tissues with $100 \%$ specificity [97]. Moreover, hypermethylation of MGMT and THBS1 in CSF were the only independent prognostic factors, indicating that CSF also captures epigenomic alterations.

Additional components of liquid biopsy have been detected in CSF from glioblastoma patients. In this sense, EVs derived from CSF allowed the detection of IDH1 mutations in five out of eight patients using BEAMing and ddPCR techniques with matched corresponding IDH1 mutations in tumor tissue [109]. In addition, circulating miRNAs and EV-derived miRNAs were detected in CSF samples [98,99], and these results allowed to propose that they might serve as CSF biomarkers to diagnose and monitor therapy response in glioblastoma patients [99]. In support of this, the levels of a 
panel of nine miRNAs, including miR-21, miR-218, miR-193b, miR-331, miR374a, miR548c, miR520f, miR27b and miR-30b, in CSF from glioblastoma patients were found to correlate with those detected from tissue biopsies samples [100]. Such signature was associated with tumor volume and presented $67 \%$ sensitivity and $80 \%$ specificity [100]. Likewise, upregulated levels of miR-21, miR-10b and miR- $15 \mathrm{~b}$ in CSF have been associated with tumor stage, prognosis and response to therapy in glioblastoma patients [101-103]. Interestingly, disease progression and therapeutic response was reflected by the CSF levels of miR-21 in longitudinal samples of glioblastoma patients [102]. The presence of miR-21 together with mir-15b allowed differentiating glioblastoma from other intracranial pathologies with $90 \%$ sensitivity and 100\% specificity [101]. Likewise, these CSF miRNAs have shown to have better diagnostic value, with high sensitivity $(84 \%)$ and specificity $(92 \%)$ than serum levels to identify patients with glioblastoma. Moreover, miR-21 was highly overexpressed in glioblastoma-derived EVs (tenfold higher levels) compared to EVs isolated from the CSF of healthy patients [82]. Interestingly, analyses of longitudinal samples reported a correlation between tumor burden and EV miR-21 levels in CSF, as miR-21 content decreased after surgery [82]. Together, these results imply the relevance of miRNA profiling in CSF for glioblastoma diagnosis. Nevertheless, as stated before there is still need for further standardization of the miRNA analysis, isolation and quantification methods. Importantly, these results highlight that CSF samples stand as a source to identify diagnostic and prognostic biomarkers. Moreover, ctDNA sequencing from CSF samples could facilitate glioblastoma genotyping and characterization and might complement the information provided by other non-specific biomarkers and the imaging techniques that are currently implemented in clinical practice.

\section{Other Sources of Liquid Biopsy: Urine}

Urine represents a useful source of biomarkers as its collection is non-invasive, simple and could be repeatedly done throughout the course of the disease. In fact, ctDNA can be detected in urine after renal filtration and is referred to as transrenal DNA (trDNA). This analyte appears in urine as a result of the renal clearance of the ctDNA present in the bloodstream [112]. A panel of urinary biomarkers, comprising matrix metalloproteinases (MMPs) and VEGF, was described to possess predictive ability to detect primary brain tumors including glioblastoma with high sensitivity $(95.2 \%)$, specificity $(95.7 \%)$ and overall accuracy (92.5\%) [113]. Thus, the MMP-2, MMP-9, NGAL and VEGF markers were elevated in samples from glioblastoma patients compared to control individuals. The elevated expression in urine correlated with the increased expression of such biomarkers in the tumor tissue, as well as in the CSF in the case of MMP-9 expression. However, the diagnostic ability of the biomarker panel in glioblastoma was reduced, since it was developed for a wide variety of brain tumors and not specifically for this tumor. Additional studies and clinical trials have used urine to measure the expression of biomarkers but without robust results [114-117].

\section{Conclusions and Future Perspectives}

Glioblastoma remains one of the most aggressive human cancers with current diagnosis and prognosis based on imaging and tissue sample information. There is therefore an urgent clinical need for the identification of non-invasive methods for diagnosis, monitoring the evolution and use of genotype-directed therapies. Liquid biopsy could offer a minimally invasive possibility to unveil the molecular landscape of solid tumor samples through the analysis of biological fluids from patients.

Research in liquid biopsy is gaining remarkable interest in glioblastoma. Indeed, sampling body fluids such as blood or CSF derived from glioblastoma patients revealed that they present several circulating components that derive directly from the tumor. Thus, it might be an alternative source to tissue sample. These components include relatively well-established sources such as ctDNA, ctRNA, EVs and CTCs, or promising ones such as different metabolites and TEPs. They can have great potential to identify biomarkers for diagnosis, prognosis, and therapeutic response monitoring purposes, and could also allow genotype-directed therapies and the personalized clinical management of gliobastoma patients (Figure 2). 


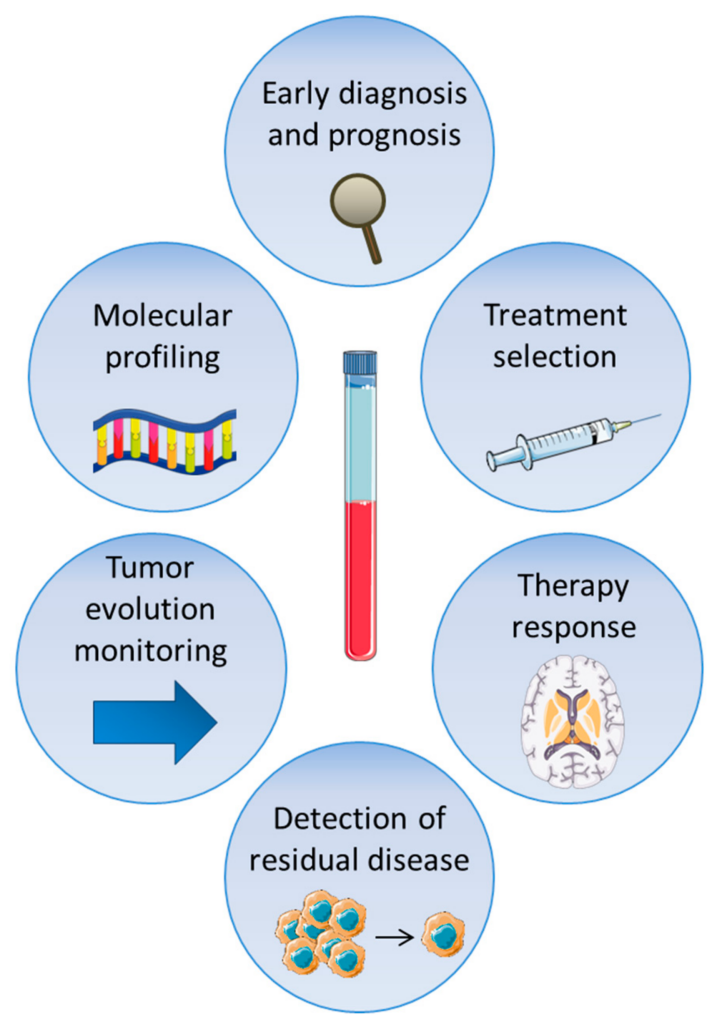

Figure 2. Potential applications of liquid biopsy in glioblastoma. The different circulating molecules may be applied to guide initial diagnosis, prognosis prediction, the molecular profiling of the tumor, treatment planning, patient follow-up, tumor evolution monitoring and the detection of glioblastoma relapse.

Since glioblastomas arise in the CNS, accessibility is a problem and the BBB hampers the release or transfer of tumor-derived material into blood, which has been the most studied biological fluid until recently. Thus, serum or plasma components, in particular tumor-derived nucleic acids, have been detected generally at low levels and this might make its implementation difficult in routine clinical practice. This might happen because the levels are insufficient to perform genotyping and detect the somatic mutations of the tumor. In order to overcome these limitations, CSF is emerging as a promising sample and, together with improved sequencing approaches with increased analytical sensitivity and specificity, it has recently shown promising results towards ctDNA analysis [96,118]. New technologic advancements could allow for continued refinements in standardization and improved signal detection in the measurement of ctDNA/ctRNA or additional circulating tumor components such as CTCs. Nonetheless, these promising non-invasive biomarkers need to be validated in large cohorts of patients in order to reveal a clinical translation. Further research contemplating the combined analysis of circulating components should be take into account, since each has the potential to capture unique aspects of the characteristics of the tumor genome, and together might become the most reliable and comprehensive tool of information.

Overall, liquid biopsy emerges as an attractive minimally invasive approach to identify diagnostic and prognostic biomarkers in biological fluids as well as a potential tool for monitoring tumor evolution, therapy response and treatment selection. Validation of the existing results is still needed and will strengthen the robustness of the data.

Funding: A.S.-A. is a recipient of predoctoral fellowship from the Instituto de Salud Carlos III (FI17/00250). J.A.-I. and L.M.-C. are recipients of predoctoral fellowships from Department of Education, University and Research of the Basque Government. E.C.-G. is a recipient of a Stop Fuga de Cerebros postdoctoral fellowship. A.M. lab is supported by grants from Instituto de Salud Carlos III and FEDER Funds (CP16/00039, DTS16/00184, PI16/01580, DTS18/00181, PI18/01612), Diputacion Guipuzcoa (112/18) and Industry and Health Departments of the Basque Country. 
Conflicts of Interest: The authors declare no conflict of interest.

\section{References}

1. Louis, D.N.; Perry, A.; Reifenberger, G.; von Deimling, A.; Figarella-Branger, D.; Cavenee, W.K.; Ohgaki, H.; Wiestler, O.D.; Kleihues, P.; Ellison, D.W. The 2016 World Health Organization Classification of Tumors of the Central Nervous System: A summary. Acta Neuropathol. 2016, 131, 803-820. [CrossRef] [PubMed]

2. Ostrom, Q.T.; Bauchet, L.; Davis, F.G.; Deltour, I.; Fisher, J.L.; Langer, C.E.; Pekmezci, M.; Schwartzbaum, J.A.; Turner, M.C.; Walsh, K.M.; et al. The epidemiology of glioma in adults: A "state of the science" review. Neuro Oncol. 2014, 16, 896-913. [CrossRef] [PubMed]

3. Stupp, R.; Mason, W.P.; van den Bent, M.J.; Weller, M.; Fisher, B.; Taphoorn, M.J.; Belanger, K.; Brandes, A.A.; Marosi, C.; Bogdahn, U.; et al. Radiotherapy plus concomitant and adjuvant temozolomide for glioblastoma. N. Engl. J. Med. 2005, 352, 987-996. [CrossRef] [PubMed]

4. Stupp, R.; Hegi, M.E.; Mason, W.P.; van den Bent, M.J.; Taphoorn, M.J.; Janzer, R.C.; Ludwin, S.K.; Allgeier, A.; Fisher, B.; Belanger, K.; et al. Effects of radiotherapy with concomitant and adjuvant temozolomide versus radiotherapy alone on survival in glioblastoma in a randomised phase III study: 5-year analysis of the EORTC-NCIC trial. Lancet Oncol. 2009, 10, 459-466. [CrossRef]

5. Brennan, C.W.; Verhaak, R.G.; McKenna, A.; Campos, B.; Noushmehr, H.; Salama, S.R.; Zheng, S.; Chakravarty, D.; Sanborn, J.Z.; Berman, S.H.; et al. The somatic genomic landscape of glioblastoma. Cell 2013, 155, 462-477. [CrossRef] [PubMed]

6. The Cancer Genome Atlas Program-National Cancer Institute. Comprehensive genomic characterization defines human glioblastoma genes and core pathways. Nature 2008, 455, 1061-1068. [CrossRef] [PubMed]

7. Verhaak, R.G.; Hoadley, K.A.; Purdom, E.; Wang, V.; Qi, Y.; Wilkerson, M.D.; Miller, C.R.; Ding, L.; Golub, T.; Mesirov, J.P.; et al. Integrated genomic analysis identifies clinically relevant subtypes of glioblastoma characterized by abnormalities in PDGFRA, IDH1, EGFR, and NF1. Cancer Cell 2010, 17, 98-110. [CrossRef]

8. Malta, T.M.; de Souza, C.F.; Sabedot, T.S.; Silva, T.C.; Mosella, M.S.; Kalkanis, S.N.; Snyder, J.; Castro, A.V.B.; Noushmehr, H. Glioma CpG island methylator phenotype (G-CIMP): Biological and clinical implications. Neuro Oncol. 2018, 20, 608-620. [CrossRef]

9. Noushmehr, H.; Weisenberger, D.J.; Diefes, K.; Phillips, H.S.; Pujara, K.; Berman, B.P.; Pan, F.; Pelloski, C.E.; Sulman, E.P.; Bhat, K.P.; et al. Identification of a CpG island methylator phenotype that defines a distinct subgroup of glioma. Cancer Cell 2010, 17, 510-522. [CrossRef]

10. Carrasco-Garcia, E.; Sampron, N.; Aldaz, P.; Arrizabalaga, O.; Villanua, J.; Barrena, C.; Ruiz, I.; Arrazola, M.; Lawrie, C.; Matheu, A. Therapeutic strategies targeting glioblastoma stem cells. Recent Pat. Anticancer Drug Discov. 2013, 8, 216-227. [CrossRef]

11. Siravegna, G.; Marsoni, S.; Siena, S.; Bardelli, A. Integrating liquid biopsies into the management of cancer. Nat. Rev. Clin. Oncol. 2017, 14, 531-548. [CrossRef] [PubMed]

12. Shankar, G.M.; Balaj, L.; Stott, S.L.; Nahed, B.; Carter, B.S. Liquid biopsy for brain tumors. Expert Rev. Mol. Diagn. 2017, 17. [CrossRef] [PubMed]

13. Cohen, J.D.; Li, L.; Wang, Y.; Thoburn, C.; Afsari, B.; Danilova, L.; Douville, C.; Javed, A.A.; Wong, F.; Mattox, A.; et al. Detection and localization of surgically resectable cancers with a multi-analyte blood test. Science 2018, 359, 926-930. [CrossRef] [PubMed]

14. Heitzer, E.; Haque, I.S.; Roberts, C.E.S.; Speicher, M.R. Current and future perspectives of liquid biopsies in genomics-driven oncology. Nat. Rev. Genet. 2019, 20, 71-88. [CrossRef] [PubMed]

15. Pantel, K. Blood-Based Analysis of Circulating Cell-Free DNA and Tumor Cells for Early Cancer Detection. PLoS Med. 2016, 13, e1002205. [CrossRef] [PubMed]

16. Bettegowda, C.; Sausen, M.; Leary, R.J.; Kinde, I.; Wang, Y.; Agrawal, N.; Bartlett, B.R.; Wang, H.; Luber, B.; Alani, R.M.; et al. Detection of circulating tumor DNA in early- and late-stage human malignancies. Sci. Transl. Med. 2014, 6, 224ra24. [CrossRef] [PubMed]

17. De Mattos-Arruda, L.; Mayor, R.; Ng, C.K.; Weigelt, B.; Martinez-Ricarte, F.; Torrejon, D.; Oliveira, M.; Arias, A.; Raventos, C.; Tang, J.; et al. Cerebrospinal fluid-derived circulating tumour DNA better represents the genomic alterations of brain tumours than plasma. Nat. Commun. 2015, 6, 8839. [CrossRef]

18. Jung, M.; Klotzek, S.; Lewandowski, M.; Fleischhacker, M.; Jung, K. Changes in concentration of DNA in serum and plasma during storage of blood samples. Clin. Chem. 2003, 49, 1028-1029. [CrossRef] 
19. Ulz, P.; Thallinger, G.G.; Auer, M.; Graf, R.; Kashofer, K.; Jahn, S.W.; Abete, L.; Pristauz, G.; Petru, E.; Geigl, J.B.; et al. Inferring expressed genes by whole-genome sequencing of plasma DNA. Nat. Genet. 2016, 48, 1273-1278. [CrossRef]

20. El Messaoudi, S.; Rolet, F.; Mouliere, F.; Thierry, A.R. Circulating cell free DNA: Preanalytical considerations. Clin. Chim. Acta 2013, 424, 222-230. [CrossRef]

21. Balana, C.; Ramirez, J.L.; Taron, M.; Roussos, Y.; Ariza, A.; Ballester, R.; Sarries, C.; Mendez, P.; Sanchez, J.J.; Rosell, R. O6-methyl-guanine-DNA methyltransferase methylation in serum and tumor DNA predicts response to 1,3-bis(2-chloroethyl)-1-nitrosourea but not to temozolamide plus cisplatin in glioblastoma multiforme. Clin. Cancer Res. 2003, 9, 1461-1468. [PubMed]

22. Shen, S.Y.; Singhania, R.; Fehringer, G.; Chakravarthy, A.; Roehrl, M.H.A.; Chadwick, D.; Zuzarte, P.C.; Borgida, A.; Wang, T.T.; Li, T.; et al. Sensitive tumour detection and classification using plasma cell-free DNA methylomes. Nature 2018, 563, 579-583. [CrossRef] [PubMed]

23. Piccioni, D.E.; Achrol, A.S.; Kiedrowski, L.A.; Banks, K.C.; Boucher, N.; Barkhoudarian, G.; Kelly, D.F.; Juarez, T.; Lanman, R.B.; Raymond, V.M.; et al. Analysis of cell-free circulating tumor DNA in 419 patients with glioblastoma and other primary brain tumors. CNS Oncol. 2019. [CrossRef] [PubMed]

24. Yang, C.; Wang, C.; Chen, X.; Chen, S.; Zhang, Y.; Zhi, F.; Wang, J.; Li, L.; Zhou, X.; Li, N.; et al. Identification of seven serum microRNAs from a genome-wide serum microRNA expression profile as potential noninvasive biomarkers for malignant astrocytomas. Int. J. Cancer 2013, 132, 116-127. [CrossRef] [PubMed]

25. Wang, Q.; Li, P.; Li, A.; Jiang, W.; Wang, H.; Wang, J.; Xie, K. Plasma specific miRNAs as predictive biomarkers for diagnosis and prognosis of glioma. J. Exp. Clin. Cancer Res. 2012, 31, 97. [CrossRef] [PubMed]

26. Regazzo, G.; Terrenato, I.; Spagnuolo, M.; Carosi, M.; Cognetti, G.; Cicchillitti, L.; Sperati, F.; Villani, V.; Carapella, C.; Piaggio, G.; et al. A restricted signature of serum miRNAs distinguishes glioblastoma from lower grade gliomas. J. Exp. Clin. Cancer Res. 2016, 35, 124. [CrossRef] [PubMed]

27. Wei, X.; Chen, D.; Lv, T.; Li, G.; Qu, S. Serum MicroRNA-125b as a Potential Biomarker for Glioma Diagnosis. Mol. Neurobiol. 2016, 53, 163-170. [CrossRef]

28. Yue, X.; Lan, F.; Hu, M.; Pan, Q.; Wang, Q.; Wang, J. Downregulation of serum microRNA-205 as a potential diagnostic and prognostic biomarker for human glioma. J. Neurosurg. 2016, 124, 122-128. [CrossRef]

29. Yang, C.H.; Yue, J.; Pfeffer, S.R.; Fan, M.; Paulus, E.; Hosni-Ahmed, A.; Sims, M.; Qayyum, S.; Davidoff, A.M.; Handorf, C.R.; et al. MicroRNA-21 promotes glioblastoma tumorigenesis by down-regulating insulin-like growth factor-binding protein-3 (IGFBP3). J. Biol. Chem. 2014, 289, 25079-25087. [CrossRef]

30. Li, W.; Guo, F.; Wang, P.; Hong, S.; Zhang, C. miR-221/222 confers radioresistance in glioblastoma cells through activating Akt independent of PTEN status. Curr. Mol. Med. 2014, 14, 185-195. [CrossRef]

31. Shao, N.; Wang, L.; Xue, L.; Wang, R.; Lan, Q. Plasma miR-454-3p as a potential prognostic indicator in human glioma. Neurol. Sci. 2015, 36, 309-313. [CrossRef] [PubMed]

32. Lai, N.S.; Wu, D.G.; Fang, X.G.; Lin, Y.C.; Chen, S.S.; Li, Z.B.; Xu, S.S. Serum microRNA-210 as a potential noninvasive biomarker for the diagnosis and prognosis of glioma. Br. J. Cancer 2015, 112, 1241-1246. [CrossRef] [PubMed]

33. Xiao, Y.; Zhang, L.; Song, Z.; Guo, C.; Zhu, J.; Li, Z.; Zhu, S. Potential Diagnostic and Prognostic Value of Plasma Circulating MicroRNA-182 in Human Glioma. Med. Sci. Monit. 2016, 22, 855-862. [CrossRef] [PubMed]

34. Tan, S.K.; Pastori, C.; Penas, C.; Komotar, R.J.; Ivan, M.E.; Wahlestedt, C.; Ayad, N.G. Serum long noncoding RNA HOTAIR as a novel diagnostic and prognostic biomarker in glioblastoma multiforme. Mol. Cancer 2018, 17, 74. [CrossRef] [PubMed]

35. Shen, J.; Hodges, T.R.; Song, R.; Gong, Y.; Calin, G.A.; Heimberger, A.B.; Zhao, H. Serum HOTAIR and GAS5 levels as predictors of survival in patients with glioblastoma. Mol. Carcinog. 2018, 57, 137-141. [CrossRef] [PubMed]

36. Zhang, J.X.; Han, L.; Bao, Z.S.; Wang, Y.Y.; Chen, L.Y.; Yan, W.; Yu, S.Z.; Pu, P.Y.; Liu, N.; You, Y.P.; et al. HOTAIR, a cell cycle-associated long noncoding RNA and a strong predictor of survival, is preferentially expressed in classical and mesenchymal glioma. Neuro Oncol. 2013, 15, 1595-1603. [CrossRef] [PubMed]

37. Kumar, D.M.; Thota, B.; Shinde, S.V.; Prasanna, K.V.; Hegde, A.S.; Arivazhagan, A.; Chandramouli, B.A.; Santosh, V.; Somasundaram, K. Proteomic identification of haptoglobin alpha2 as a glioblastoma serum biomarker: Implications in cancer cell migration and tumor growth. J. Proteome Res. 2010, 9, 5557-5567. [CrossRef] 
38. Qin, G.; Li, X.; Chen, Z.; Liao, G.; Su, Y.; Chen, Y.; Zhang, W. Prognostic Value of YKL-40 in Patients with Glioblastoma: A Systematic Review and Meta-analysis. Mol. Neurobiol. 2017, 54, 3264-3270. [CrossRef]

39. Iwamoto, F.M.; Hottinger, A.F.; Karimi, S.; Riedel, E.; Dantis, J.; Jahdi, M.; Panageas, K.S.; Lassman, A.B.; Abrey, L.E.; Fleisher, M.; et al. Serum YKL-40 is a marker of prognosis and disease status in high-grade gliomas. Neuro Oncol. 2011, 13, 1244-1251. [CrossRef]

40. Petrik, V.; Saadoun, S.; Loosemore, A.; Hobbs, J.; Opstad, K.S.; Sheldon, J.; Tarelli, E.; Howe, F.A.; Bell, B.A.; Papadopoulos, M.C. Serum alpha 2-HS glycoprotein predicts survival in patients with glioblastoma. Clin. Chem. 2008, 54, 713-722. [CrossRef]

41. Osti, D.; Del Bene, M.; Rappa, G.; Santos, M.; Matafora, V.; Richichi, C.; Faletti, S.; Beznoussenko, G.V.; Mironov, A.; Bachi, A.; et al. Clinical Significance of Extracellular Vesicles in Plasma from Glioblastoma Patients. Clin. Cancer Res. 2019, 25, 266-276. [CrossRef] [PubMed]

42. Shao, H.; Chung, J.; Balaj, L.; Charest, A.; Bigner, D.D.; Carter, B.S.; Hochberg, F.H.; Breakefield, X.O.; Weissleder, R.; Lee, H. Protein typing of circulating microvesicles allows real-time monitoring of glioblastoma therapy. Nat. Med. 2012, 18, 1835-1840. [CrossRef] [PubMed]

43. Garcia-Romero, N.; Carrion-Navarro, J.; Esteban-Rubio, S.; Lazaro-Ibanez, E.; Peris-Celda, M.; Alonso, M.M.; Guzman-De-Villoria, J.; Fernandez-Carballal, C.; de Mendivil, A.O.; Garcia-Duque, S.; et al. DNA sequences within glioma-derived extracellular vesicles can cross the intact blood-brain barrier and be detected in peripheral blood of patients. Oncotarget 2017, 8, 1416-1428. [CrossRef] [PubMed]

44. Ramakrishnan, V.; Kushwaha, D.; Koay, D.C.; Reddy, H.; Mao, Y.; Zhou, L.; Ng, K.; Zinn, P.; Carter, B.; Chen, C.C. Post-transcriptional regulation of O (6)-methylguanine-DNA methyltransferase MGMT in glioblastomas. Cancer Biomark. 2011, 10, 185-193. [CrossRef] [PubMed]

45. Ricklefs, F.L.; Alayo, Q.; Krenzlin, H.; Mahmoud, A.B.; Speranza, M.C.; Nakashima, H.; Hayes, J.L.; Lee, K.; Balaj, L.; Passaro, C.; et al. Immune evasion mediated by PD-L1 on glioblastoma-derived extracellular vesicles. Sci. Adv. 2018, 4, eaar2766. [CrossRef]

46. Garnier, D.; Meehan, B.; Kislinger, T.; Daniel, P.; Sinha, A.; Abdulkarim, B.; Nakano, I.; Rak, J. Divergent evolution of temozolomide resistance in glioblastoma stem cells is reflected in extracellular vesicles and coupled with radiosensitization. Neuro Oncol. 2018, 20, 236-248. [CrossRef]

47. Sullivan, J.P.; Nahed, B.V.; Madden, M.W.; Oliveira, S.M.; Springer, S.; Bhere, D.; Chi, A.S.; Wakimoto, H.; Rothenberg, S.M.; Sequist, L.V.; et al. Brain tumor cells in circulation are enriched for mesenchymal gene expression. Cancer Discov. 2014, 4, 1299-1309. [CrossRef]

48. Gao, F.; Cui, Y.; Jiang, H.; Sui, D.; Wang, Y.; Jiang, Z.; Zhao, J.; Lin, S. Circulating tumor cell is a common property of brain glioma and promotes the monitoring system. Oncotarget 2016, 7, 71330-71340. [CrossRef]

49. Muller, C.; Holtschmidt, J.; Auer, M.; Heitzer, E.; Lamszus, K.; Schulte, A.; Matschke, J.; Langer-Freitag, S.; Gasch, C.; Stoupiec, M.; et al. Hematogenous dissemination of glioblastoma multiforme. Sci. Transl. Med. 2014, 6, 247ra101. [CrossRef]

50. Liu, T.; Xu, H.; Huang, M.; Ma, W.; Saxena, D.; Lustig, R.A.; Alonso-Basanta, M.; Zhang, Z.; O’Rourke, D.M.; Zhang, L.; et al. Circulating Glioma Cells Exhibit Stem Cell-like Properties. Cancer Res. 2018, 78, 6632-6642. [CrossRef]

51. Van Schaijik, B.; Wickremesekera, A.C.; Mantamadiotis, T.; Kaye, A.H.; Tan, S.T.; Stylli, S.S.; Itinteang, T. Circulating tumor stem cells and glioblastoma: A review. J. Clin. Neurosci. 2019, 61, 5-9. [CrossRef] [PubMed]

52. Nilsson, R.J.; Balaj, L.; Hulleman, E.; van Rijn, S.; Pegtel, D.M.; Walraven, M.; Widmark, A.; Gerritsen, W.R.; Verheul, H.M.; Vandertop, W.P.; et al. Blood platelets contain tumor-derived RNA biomarkers. Blood 2011, 118, 3680-3683. [CrossRef] [PubMed]

53. Perkins, G.; Lu, H.; Garlan, F.; Taly, V. Droplet-Based Digital PCR: Application in Cancer Research. Adv. Clin. Chem. 2017, 79, 43-91. [PubMed]

54. Newman, A.M.; Bratman, S.V.; To, J.; Wynne, J.F.; Eclov, N.C.; Modlin, L.A.; Liu, C.L.; Neal, J.W.; Wakelee, H.A.; Merritt, R.E.; et al. An ultrasensitive method for quantitating circulating tumor DNA with broad patient coverage. Nat. Med. 2014, 20, 548-554. [CrossRef] [PubMed]

55. Postel, M.; Roosen, A.; Laurent-Puig, P.; Taly, V.; Wang-Renault, S.F. Droplet-based digital PCR and next generation sequencing for monitoring circulating tumor DNA: A cancer diagnostic perspective. Expert Rev. Mol. Diagn. 2018, 18, 7-17. [CrossRef] [PubMed] 
56. Zhong, Q.; Bhattacharya, S.; Kotsopoulos, S.; Olson, J.; Taly, V.; Griffiths, A.D.; Link, D.R.; Larson, J.W. Multiplex digital PCR: Breaking the one target per color barrier of quantitative PCR. Lab. A Chip 2011, 11, 2167-2174. [CrossRef]

57. Wang, J.; Zhao, Y.Y.; Li, J.F.; Guo, C.C.; Chen, F.R.; Su, H.K.; Zhao, H.F.; Long, Y.K.; Shao, J.Y.; To, S.; et al. IDH1 mutation detection by droplet digital PCR in glioma. Oncotarget 2015, 6, 39651-39660. [CrossRef]

58. Zill, O.A.; Banks, K.C.; Fairclough, S.R.; Mortimer, S.A.; Vowles, J.V.; Mokhtari, R.; Gandara, D.R.; Mack, P.C.; Odegaard, J.I.; Nagy, R.J.; et al. The Landscape of Actionable Genomic Alterations in Cell-Free Circulating Tumor DNA from 21,807 Advanced Cancer Patients. Clin. Cancer Res. 2018, 24, 3528-3538. [CrossRef]

59. Schwaederle, M.; Husain, H.; Fanta, P.T.; Piccioni, D.E.; Kesari, S.; Schwab, R.B.; Banks, K.C.; Lanman, R.B.; Talasaz, A.; Parker, B.A.; et al. Detection rate of actionable mutations in diverse cancers using a biopsy-free (blood) circulating tumor cell DNA assay. Oncotarget 2016, 7, 9707-9717. [CrossRef]

60. Chen, J.; Huan, W.; Zuo, H.; Zhao, L.; Huang, C.; Liu, X.; Hou, S.; Qi, J.; Shi, W. Alu methylation serves as a biomarker for non-invasive diagnosis of glioma. Oncotarget 2016, 7, 26099-26106. [CrossRef]

61. Schwarzenbach, H.; Nishida, N.; Calin, G.A.; Pantel, K. Clinical relevance of circulating cell-free microRNAs in cancer. Nat. Rev. Clin. Oncol. 2014, 11, 145-156. [CrossRef] [PubMed]

62. Montani, F.; Bianchi, F. Circulating Cancer Biomarkers: The Macro-revolution of the Micro-RNA. EBioMedicine 2016, 5, 4-6. [CrossRef] [PubMed]

63. Weber, J.A.; Baxter, D.H.; Zhang, S.; Huang, D.Y.; Huang, K.H.; Lee, M.J.; Galas, D.J.; Wang, K. The microRNA spectrum in 12 body fluids. Clin. Chem. 2010, 56, 1733-1741. [CrossRef] [PubMed]

64. Calin, G.A.; Croce, C.M. MicroRNA signatures in human cancers. Nat. Rev. Cancer 2006, 6, 857-866. [CrossRef] [PubMed]

65. Rynkeviciene, R.; Simiene, J.; Strainiene, E.; Stankevicius, V.; Usinskiene, J.; Miseikyte Kaubriene, E.; Meskinyte, I.; Cicenas, J.; Suziedelis, K. Non-Coding RNAs in Glioma. Cancers 2018, 11, 17. [CrossRef] [PubMed]

66. Ahir, B.K.; Ozer, H.; Engelhard, H.H.; Lakka, S.S. MicroRNAs in glioblastoma pathogenesis and therapy: A comprehensive review. Crit. Rev. Oncol. Hematol. 2017, 120, 22-33. [CrossRef]

67. Fontanilles, M.; Duran-Pena, A.; Idbaih, A. Liquid Biopsy in Primary Brain Tumors: Looking for Stardust! Curr. Neurol. Neurosci. Rep. 2018, 18, 13. [CrossRef]

68. Torres-Bayona, S.; Aldaz, P.; Auzmendi-Iriarte, J.; Saenz-Antonanzas, A.; Garcia, I.; Arrazola, M.; Gerovska, D.; Undabeitia, J.; Querejeta, A.; Egana, L.; et al. PR-LncRNA signature regulates glioma cell activity through expression of SOX factors. Sci. Rep. 2018, 8, 12746. [CrossRef]

69. Zhu, J.; Ye, J.; Zhang, L.; Xia, L.; Hu, H.; Jiang, H.; Wan, Z.; Sheng, F.; Ma, Y.; Li, W.; et al. Differential Expression of Circular RNAs in Glioblastoma Multiforme and Its Correlation with Prognosis. Transl. Oncol. 2017, 10, 271-279. [CrossRef]

70. Chen, L.; Han, L.; Wei, J.; Zhang, K.; Shi, Z.; Duan, R.; Li, S.; Zhou, X.; Pu, P.; Zhang, J.; et al. SNORD76, a box C/D snoRNA, acts as a tumor suppressor in glioblastoma. Sci. Rep. 2015, 5, 8588. [CrossRef]

71. Raposo, G.; Stoorvogel, W. Extracellular vesicles: Exosomes, microvesicles, and friends. J. Cell Biol. 2013, 200, 373-383. [CrossRef] [PubMed]

72. Tkach, M.; Thery, C. Communication by Extracellular Vesicles: Where We Are and Where We Need to Go. Cell 2016, 164, 1226-1232. [CrossRef] [PubMed]

73. Yanez-Mo, M.; Siljander, P.R.; Andreu, Z.; Zavec, A.B.; Borras, F.E.; Buzas, E.I.; Buzas, K.; Casal, E.; Cappello, F.; Carvalho, J.; et al. Biological properties of extracellular vesicles and their physiological functions. J. Extracell. Vesicles 2015, 4, 27066. [CrossRef] [PubMed]

74. Manterola, L.; Guruceaga, E.; Gallego Perez-Larraya, J.; Gonzalez-Huarriz, M.; Jauregui, P.; Tejada, S.; Diez-Valle, R.; Segura, V.; Sampron, N.; Barrena, C.; et al. A small noncoding RNA signature found in exosomes of GBM patient serum as a diagnostic tool. Neuro Oncol. 2014, 16, 520-527. [CrossRef] [PubMed]

75. Santiago-Dieppa, D.R.; Steinberg, J.; Gonda, D.; Cheung, V.J.; Carter, B.S.; Chen, C.C. Extracellular vesicles as a platform for 'liquid biopsy' in glioblastoma patients. Expert Rev. Mol. Diagn. 2014, 14, 819-825. [CrossRef] [PubMed]

76. Gourlay, J.; Morokoff, A.P.; Luwor, R.B.; Zhu, H.J.; Kaye, A.H.; Stylli, S.S. The emergent role of exosomes in glioma. J. Clin. Neurosci. 2017, 35, 13-23. [CrossRef] [PubMed] 
77. Thakur, B.K.; Zhang, H.; Becker, A.; Matei, I.; Huang, Y.; Costa-Silva, B.; Zheng, Y.; Hoshino, A.; Brazier, H.; Xiang, J.; et al. Double-stranded DNA in exosomes: A novel biomarker in cancer detection. Cell Res. 2014, 24, 766-769. [CrossRef]

78. Skog, J.; Wurdinger, T.; van Rijn, S.; Meijer, D.H.; Gainche, L.; Sena-Esteves, M.; Curry, W.T., Jr.; Carter, B.S.; Krichevsky, A.M.; Breakefield, X.O. Glioblastoma microvesicles transport RNA and proteins that promote tumour growth and provide diagnostic biomarkers. Nat. Cell Biol. 2008, 10, 1470-1476. [CrossRef]

79. Bible, E. Neuro-oncology: Glioblastoma detection and therapy monitoring by microvesicle release. Nat. Rev. Neurol. 2013, 9, 4. [CrossRef]

80. Mondal, A.; Kumari Singh, D.; Panda, S.; Shiras, A. Extracellular Vesicles as Modulators of Tumor Microenvironment and Disease Progression in Glioma. Front. Oncol. 2017, 7, 144. [CrossRef]

81. Mohme, M.; Riethdorf, S.; Pantel, K. Circulating and disseminated tumour cells-mechanisms of immune surveillance and escape. Nat. Rev. Clin. Oncol. 2017, 14, 155-167. [CrossRef] [PubMed]

82. Akers, J.C.; Ramakrishnan, V.; Kim, R.; Skog, J.; Nakano, I.; Pingle, S.; Kalinina, J.; Hua, W.; Kesari, S.; Mao, Y.; et al. MiR-21 in the extracellular vesicles (EVs) of cerebrospinal fluid (CSF): A platform for glioblastoma biomarker development. PLoS ONE 2013, 8, e78115. [CrossRef] [PubMed]

83. Zachariah, M.A.; Oliveira-Costa, J.P.; Carter, B.S.; Stott, S.L.; Nahed, B.V. Blood-based biomarkers for the diagnosis and monitoring of gliomas. Neuro Oncol. 2018, 20, 1155-1161. [CrossRef] [PubMed]

84. Cabel, L.; Proudhon, C.; Gortais, H.; Loirat, D.; Coussy, F.; Pierga, J.Y.; Bidard, F.C. Circulating tumor cells: Clinical validity and utility. Int. J. Clin. Oncol. 2017, 22, 421-430. [CrossRef] [PubMed]

85. Vitak, S.A.; Torkenczy, K.A.; Rosenkrantz, J.L.; Fields, A.J.; Christiansen, L.; Wong, M.H.; Carbone, L.; Steemers, F.J.; Adey, A. Sequencing thousands of single-cell genomes with combinatorial indexing. Nat. Methods 2017, 14, 302-308. [CrossRef] [PubMed]

86. Clark, S.J.; Lee, H.J.; Smallwood, S.A.; Kelsey, G.; Reik, W. Single-cell epigenomics: Powerful new methods for understanding gene regulation and cell identity. Genome Biol. 2016, 17, 72. [CrossRef]

87. Toss, A.; Mu, Z.; Fernandez, S.; Cristofanilli, M. CTC enumeration and characterization: Moving toward personalized medicine. Ann. Transl. Med. 2014, 2, 108.

88. Gollapalli, K.; Ray, S.; Srivastava, R.; Renu, D.; Singh, P.; Dhali, S.; Bajpai Dikshit, J.; Srikanth, R.; Moiyadi, A.; Srivastava, S. Investigation of serum proteome alterations in human glioblastoma multiforme. Proteomics 2012, 12, 2378-2390. [CrossRef]

89. Van Linde, M.E.; van der Mijn, J.C.; Pham, T.V.; Knol, J.C.; Wedekind, L.E.; Hovinga, K.E.; Aliaga, E.S.; Buter, J.; Jimenez, C.R.; Reijneveld, J.C.; et al. Evaluation of potential circulating biomarkers for prediction of response to chemoradiation in patients with glioblastoma. J. Neuro Oncol. 2016, 129, 221-230. [CrossRef]

90. Shen, J.; Song, R.; Hodges, T.R.; Heimberger, A.B.; Zhao, H. Identification of metabolites in plasma for predicting survival in glioblastoma. Mol. Carcinog. 2018, 57, 1078-1084. [CrossRef]

91. Bjorkblom, B.; Wibom, C.; Jonsson, P.; Moren, L.; Andersson, U.; Johannesen, T.B.; Langseth, H.; Antti, H.; Melin, B. Metabolomic screening of pre-diagnostic serum samples identifies association between alpha-and gamma-tocopherols and glioblastoma risk. Oncotarget 2016, 7, 37043-37053. [CrossRef] [PubMed]

92. Joosse, S.A.; Pantel, K. Tumor-Educated Platelets as Liquid Biopsy in Cancer Patients. Cancer Cell 2015, 28, 552-554. [CrossRef] [PubMed]

93. In 't Veld, S.; Wurdinger, T. Tumor-educated platelets. Blood 2019. [CrossRef] [PubMed]

94. Best, M.G.; Wesseling, P.; Wurdinger, T. Tumor-Educated Platelets as a Noninvasive Biomarker Source for Cancer Detection and Progression Monitoring. Cancer Res. 2018, 78, 3407-3412. [CrossRef] [PubMed]

95. Best, M.G.; Sol, N.; Kooi, I.; Tannous, J.; Westerman, B.A.; Rustenburg, F.; Schellen, P.; Verschueren, H.; Post, E.; Koster, J.; et al. RNA-Seq of Tumor-Educated Platelets Enables Blood-Based Pan-Cancer, Multiclass, and Molecular Pathway Cancer Diagnostics. Cancer Cell. 2015, 28, 666-676. [CrossRef] [PubMed]

96. Miller, A.M.; Shah, R.H.; Pentsova, E.I.; Pourmaleki, M.; Briggs, S.; Distefano, N.; Zheng, Y.; Skakodub, A.; Mehta, S.A.; Campos, C.; et al. Tracking tumour evolution in glioma through liquid biopsies of cerebrospinal fluid. Nature 2019, 565, 654-658. [CrossRef] [PubMed]

97. Liu, B.L.; Cheng, J.X.; Zhang, W.; Zhang, X.; Wang, R.; Lin, H.; Huo, J.L.; Cheng, H. Quantitative detection of multiple gene promoter hypermethylation in tumor tissue, serum, and cerebrospinal fluid predicts prognosis of malignant gliomas. Neuro Oncol. 2010, 12, 540-548. [CrossRef] [PubMed] 
98. Drusco, A.; Bottoni, A.; Lagana, A.; Acunzo, M.; Fassan, M.; Cascione, L.; Antenucci, A.; Kumchala, P.; Vicentini, C.; Gardiman, M.P.; et al. A differentially expressed set of microRNAs in cerebro-spinal fluid (CSF) can diagnose CNS malignancies. Oncotarget 2015, 6, 20829-20839. [CrossRef]

99. Kopkova, A.; Sana, J.; Fadrus, P.; Slaby, O. Cerebrospinal fluid microRNAs as diagnostic biomarkers in brain tumors. Clin. Chem. Lab. Med. 2018, 56, 869-879. [CrossRef]

100. Akers, J.C.; Hua, W.; Li, H.; Ramakrishnan, V.; Yang, Z.; Quan, K.; Zhu, W.; Li, J.; Figueroa, J.; Hirshman, B.R.; et al. A cerebrospinal fluid microRNA signature as biomarker for glioblastoma. Oncotarget 2017, 8, 68769-68779. [CrossRef]

101. Baraniskin, A.; Kuhnhenn, J.; Schlegel, U.; Maghnouj, A.; Zollner, H.; Schmiegel, W.; Hahn, S.; Schroers, R. Identification of microRNAs in the cerebrospinal fluid as biomarker for the diagnosis of glioma. Neuro Oncol. 2012, 14, 29-33. [CrossRef] [PubMed]

102. Teplyuk, N.M.; Mollenhauer, B.; Gabriely, G.; Giese, A.; Kim, E.; Smolsky, M.; Kim, R.Y.; Saria, M.G.; Pastorino, S.; Kesari, S.; et al. MicroRNAs in cerebrospinal fluid identify glioblastoma and metastatic brain cancers and reflect disease activity. Neuro Oncol. 2012, 14, 689-700. [CrossRef] [PubMed]

103. Qu, K.; Lin, T.; Pang, Q.; Liu, T.; Wang, Z.; Tai, M.; Meng, F.; Zhang, J.; Wan, Y.; Mao, P.; et al. Extracellular miRNA-21 as a novel biomarker in glioma: Evidence from meta-analysis, clinical validation and experimental investigations. Oncotarget 2016, 7, 33994-34010. [CrossRef] [PubMed]

104. Yoshida, J.; Wakabayashi, T.; Okamoto, S.; Kimura, S.; Washizu, K.; Kiyosawa, K.; Mokuno, K. Tenascin in cerebrospinal fluid is a useful biomarker for the diagnosis of brain tumour. J. Neurol. Neurosurg. Psychiatr. 1994, 57, 1212-1215. [CrossRef] [PubMed]

105. Schuhmann, M.U.; Zucht, H.D.; Nassimi, R.; Heine, G.; Schneekloth, C.G.; Stuerenburg, H.J.; Selle, H. Peptide screening of cerebrospinal fluid in patients with glioblastoma multiforme. Eur. J. Surg. Oncol. J. Eur. Soc. Surg. Oncol. Br. Assoc. Surg. Oncol. 2010, 36, 201-207. [CrossRef] [PubMed]

106. Yamaguchi, Y.; Shao, Z.; Sharif, S.; Du, X.Y.; Myles, T.; Merchant, M.; Harsh, G.; Glantz, M.; Recht, L.; Morser, J.; et al. Thrombin-cleaved fragments of osteopontin are overexpressed in malignant glial tumors and provide a molecular niche with survival advantage. J. Biol. Chem. 2013, 288, 3097-3111. [CrossRef] [PubMed]

107. Peles, E.; Lidar, Z.; Simon, A.J.; Grossman, R.; Nass, D.; Ram, Z. Angiogenic factors in the cerebrospinal fluid of patients with astrocytic brain tumors. Neurosurgery 2004, 55, 562-567. [CrossRef] [PubMed]

108. Li, Q.Y.; Yang, Y.; Zhang, Y.; Zhang, Z.J.; Gong, A.H.; Yuan, Z.C.; Lu, P.S.; Zhan, L.P.; Wang, P.; Feng, Y.; et al. Nerve growth factor expression in astrocytoma and cerebrospinal fluid: A new biomarker for prognosis of astrocytoma. Chin. Med. J. 2011, 124, 2222-2227.

109. Chen, W.W.; Balaj, L.; Liau, L.M.; Samuels, M.L.; Kotsopoulos, S.K.; Maguire, C.A.; Loguidice, L.; Soto, H.; Garrett, M.; Zhu, L.D.; et al. BEAMing and Droplet Digital PCR Analysis of Mutant IDH1 mRNA in Glioma Patient Serum and Cerebrospinal Fluid Extracellular Vesicles. Mol. Ther. Nucleic Acids 2013, 2, e109. [CrossRef]

110. Wang, Y.; Springer, S.; Zhang, M.; McMahon, K.W.; Kinde, I.; Dobbyn, L.; Ptak, J.; Brem, H.; Chaichana, K.; Gallia, G.L.; et al. Detection of tumor-derived DNA in cerebrospinal fluid of patients with primary tumors of the brain and spinal cord. Proc. Natl. Acad. Sci. USA 2015, 112, 9704-9709. [CrossRef]

111. Pentsova, E.I.; Shah, R.H.; Tang, J.; Boire, A.; You, D.; Briggs, S.; Omuro, A.; Lin, X.; Fleisher, M.; Grommes, C.; et al. Evaluating Cancer of the Central Nervous System Through Next-Generation Sequencing of Cerebrospinal Fluid. J. Clin. Oncol. 2016, 34, 2404-2415. [CrossRef] [PubMed]

112. Botezatu, I.; Serdyuk, O.; Potapova, G.; Shelepov, V.; Alechina, R.; Molyaka, Y.; Ananev, V.; Bazin, I.; Garin, A.; Narimanov, M.; et al. Genetic analysis of DNA excreted in urine: A new approach for detecting specific genomic DNA sequences from cells dying in an organism. Clin. Chem. 2000, 46, 1078-1084. [PubMed]

113. Smith, E.R.; Zurakowski, D.; Saad, A.; Scott, R.M.; Moses, M.A. Urinary biomarkers predict brain tumor presence and response to therapy. Clin. Cancer Res. 2008, 14, 2378-2386. [CrossRef] [PubMed]

114. Takano, S.; Ishikawa, E.; Nakai, K.; Matsuda, M.; Masumoto, T.; Yamamoto, T.; Matsumura, A. Bevacizumab in Japanese patients with malignant glioma: From basic research to clinical trial. OncoTargets Ther. 2014, 7, 1551-1562. [CrossRef] [PubMed] 
115. Krauze, A.V.; Won, M.; Graves, C.; Corn, B.W.; Muanza, T.M.; Howard, S.P.; Mahadevan, A.; Schultz, C.J.; Haas, M.L.; Mehta, M.P.; et al. Predictive value of tumor recurrence using urinary vascular endothelial factor levels in patients receiving radiation therapy for Glioblastoma Multiforme (GBM). Biomark. Res. 2013, 1, 29. [CrossRef]

116. Rieger, J.; Bahr, O.; Maurer, G.D.; Hattingen, E.; Franz, K.; Brucker, D.; Walenta, S.; Kammerer, U.; Coy, J.F.; Weller, M.; et al. ERGO: A pilot study of ketogenic diet in recurrent glioblastoma. Int. J. Oncol. 2014, 44, 1843-1852. [CrossRef] [PubMed]

117. Mair, R.; Mouliere, F.; Smith, C.G.; Chandrananda, D.; Gale, D.; Marass, F.; Tsui, D.W.Y.; Massie, C.E.; Wright, A.J.; Watts, C.; et al. Measurement of Plasma Cell-Free Mitochondrial Tumor DNA Improves Detection of Glioblastoma in Patient-Derived Orthotopic Xenograft Models. Cancer Res. 2019, 79, 220-230. [CrossRef]

118. Milbury, C.A.; Zhong, Q.; Lin, J.; Williams, M.; Olson, J.; Link, D.R.; Hutchison, B. Determining lower limits of detection of digital PCR assays for cancer-related gene mutations. Biomol. Detect. Quantif. 2014, 1, 8-22. [CrossRef]

(C) 2019 by the authors. Licensee MDPI, Basel, Switzerland. This article is an open access article distributed under the terms and conditions of the Creative Commons Attribution (CC BY) license (http://creativecommons.org/licenses/by/4.0/). 